\title{
To Evaluate the Efficacy of Mukkadi Bidalaka and Patoladi Kashaya Parisheka in the management of Anjananamika (External Hordeolum) - A Single case study
}

\author{
Case Report
}

\section{Vidya N V1', Sooriyaarachchi B S M M11, Bineesh E P², Vaghela D B33}

1. PG. Scholar, 2. Ph.D Scholar, 3. I/C HOD \& Associate Professor, Department of Shalakya Tantra, Institute of Teaching and Research in Ayurveda, Jamnagar, Gujarat.

\begin{abstract}
Anjananamika is a Raktapradhana Vartmagata Sadhya Netra Vikara caused by the vitiation of Rakta and Mamsa of Vartma due to improper Ahara and Viharas. The Lakshanas of Anjannamika appears to be similar to that of Hordeolum externum, acute suppurative inflammation of the eyelash follicles and its associated glands of Zeis or Moll. It is a Raktapradhana Vyadhi along with the involvement of other Doshas, Pittahara and Doshahara treatment can be done. All the drugs in Mukkadi Bidalaka and Patoladi Kashaya Parisheka are Chakshushya and have Pitta Shamaka properties. The case selected in this study, patient has been suffering from pain, foreign body sensation, discomfort, congestion, mild watering and photophobia in the upper palpebral conjunctiva of the left eye. Mukkadi Bidalaka and Parisheka was administered twice a day for 5 days, with follow up of one week in Anjananamika. Here, a sincere effort is made to evaluate the effect of Mukkadi Bidalaka and Patoladi Kashaya Parisheka. Clinical data collected in 5 days course shows complete relief from the symptoms.
\end{abstract}

Key Words: Anjananamika, External Hordeolum, Bidalaka, Netraparisheka.

\section{Introduction}

According to Acharya Sushruta, Anjananamika is a small abscess on the lid margin which is soft, moderately painful, copper red in color and characterized by burning and pricking sensations. (1) In addition to this, Acharya Vagbhatta mentioned Anjananamika situated in the middle or the end of the eye lids, and the shape and size of the Pitaka resemble green gram. (2) It can be compared to as External hordeolum or Stye or zeis gland cyst. The causative organism involved is Staphylococcus aureus. (3)

Hordeola are very common, So the worldwide incidence of External hordeolum is unknown. In India more than one million cases of Stye is reporter per year. Stye is more common in children and young adults (though no age is bar) and in patients with eye strain due to refractive errors or muscle imbalance. Constant rubbing of the eyes or fingering of the lids and nose, chronic blepharitis and diabetes mellitus are usually associated with recurrent Stye. The Ayurvedic intervention of Anjananamika includes Swedana (Hot compresses), Nishpeedana (If spontaneously burst open, it should be well pressed and rubbed), Bhedana (Puncturing of the Pitaka), Pratisarana (Paste should be

* Corresponding Author:

Vidya N V

PG Scholar,

Department of Shalakya Tantra

Institute of Teaching and Research in Ayurveda,

Jamnagar, Gujarat. India.

Email Id: vidyakunku@gmail.com applied with the pressure of the fingers) and Raktamokshana by Jaloukavacharana. $(4,5)$

In modern medicine the signs of stye have two stages. Stage of cellulitis is characterized by localized swelling at the lid margin associated with marked edema and Stage of abscess formation is characterized by a visible pus point at the lid margin in relation to the afflicted cilia. It is treated with hot compresses 2-3 times a day, Antibiotic eyedrops (3-4 times a day), Systemic anti-inflammatory and analgesics relieve pain and reduce edema, and eye ointment at bed time, which may have many side effects. These may cause temporary stinging, swelling, burning sensation and irritation to the eyes. In addition to that, these drugs should be used frequently at a gap of 1-2 hours which may not be convenient for the student's group and working class also takes its own time to act and provides results. Its prolonged use can cause irritation and dryness to the eyes.

Due to the prevalence of the disease and the effect of the topical antibiotics and ointments, an attempt has been made to evaluate the effect of Mukkadi Bidalaka and Patoladi Kashaya Parisheka in Anjananamika.

\section{Aims and Objectives}

To evaluate the effect of Mukkadi Bidalaka and Patoladi Kashaya Parisheka in Anjananamika.

\section{Materials and Methods Study setting}

OPD (Outpatient Department) of Shalakya Tantra department, I.T.R.A., Jamnagar, Gujarat, India. 
Vidya N V et.al., Efficacy of Mukkadi Bidalaka and Patoladi Kashaya Parisheka in the management of Anjananamika

\section{Case Study}

A 33 years old male patient having symptoms of pain, foreign body sensation, discomfort, congestion, mild watering and photophobia in the upper palpebral conjunctiva of the left eye for 04 days, had chosen for the study.

\section{History of present illness}

Patient was apparently normal before 4 days, due to his overtime work in the factory near fire more than 8 hours at night, led the patient to felt pain and irritation in the left eye associated with foreign body sensation, discomfort, mild watering and photophobia, later the patient noticed marked congestion in upper palpebral conjunctiva with mild swelling. Being a factory worker, the disease in the patient had been aggravated by prolonged exposure to fire, excessive mobile phone usage, inadequate sleep. Patient was willing to take Ayurvedic medication, so he came to Eye OPD of Shalakya Tantra department, I.T.R.A., Jamnagar, for better management.

\section{History of past illness:}

No history of Diabetes mellitus, Hypertension and Thyroid disorders.

\section{Personal history:}

Personal history has mentioned in Table 1.

Table 1: Personal history

\begin{tabular}{l|l} 
Micturition & Day time 3-4 times, At night -0 times \\
$\begin{array}{l}\text { Bowel habit } \\
\text { Sleep }\end{array}$ & $\begin{array}{l}\text { Regular -2 times/day } \\
\text { Disturbed sleep due to overtime work in } \\
\text { factory } \\
\text { At night 2-3 hours } \\
\text { Day time-no }\end{array}$ \\
\hline $\begin{array}{l}\text { Addiction } \\
\text { Blood Pressure }\end{array}$ & $\begin{array}{l}\text { No any } \\
120 / 80 \mathrm{mmHg}\end{array}$ \\
$\begin{array}{l}\text { Pulse rate } \\
\text { Respiratory rate }\end{array}$ & $\begin{array}{l}74 / \mathrm{min} \\
\text { 18 }\end{array}$
\end{tabular}

\section{Clinical findings}

\section{Ashtavidha pariksha}

Ashtavidha pariksha (Eight-fold classifications) has been mentioned in Table 2 .

\section{Table 2: Ashtavidha pariksha}

\begin{tabular}{|l|l|} 
Nadi & Dosha -Vatapittaja, Regular \\
\hline Mutra & Day time 3-4 times, At night -0 times \\
\hline Mala & $1-2$ times in a day/Prakruta \\
\hline Jihva & Nirama \\
\hline Shabda & Spashta \\
\hline Sparsha & Ruksha \\
\hline Drik & Vikruta \\
Akriti & Madhyama
\end{tabular}

\section{Diagnostic focus and Assessment}

On Examination:

On Examination has been mentioned in Table 3.
Table 3: On Examination

\begin{tabular}{|c|c|c|}
\hline Structures & Right Eye & Left Eye \\
\hline Eyelids & NAD & $\begin{array}{l}\text { Generalized swelling in the } \\
\text { upper eye lid. Pus point with } \\
\text { marked congestion visible } \\
\text { on the lid margin in the } \\
\text { center cilia of upper eyelid. }\end{array}$ \\
\hline $\begin{array}{l}\text { Palpebral } \\
\text { Conjunctiva }\end{array}$ & NAD & $\begin{array}{l}\text { Swelling with marked } \\
\text { Congestion }\end{array}$ \\
\hline $\begin{array}{l}\text { Bulbar } \\
\text { conjunctiva }\end{array}$ & NAD & NAD \\
\hline Cornea & Clear & Clear \\
\hline Pupil & NS/NR & NS/NR \\
\hline Lens & Transparent & Transparent \\
\hline
\end{tabular}

Gradation of signs and symptoms of Anjananamika (External Hordeolum) is according to Ayurvedic and Modern signs and symptoms.

\section{Assessment Criteria}

Subjective Parameters

Table 4: Grading of Daha (Burning Sensation)

\begin{tabular}{|l|l|c|}
\hline Absent & Daha (Burning Sensation) & Score \\
\hline Mild & $\begin{array}{l}\text { Oc Burning sensation } \\
\text { not disturbing present Burning sensation routine }\end{array}$ & 1 \\
\hline Sederate & $\begin{array}{l}\text { Frequently present Burning sensation, } \\
\text { disturbing daily routine }\end{array}$ & 2 \\
\hline $\begin{array}{l}\text { Present throughout the day Burning } \\
\text { sensation, disturbing daily routine }\end{array}$ & 3 \\
\hline
\end{tabular}

Table 5: Grading of Toda (Pricking Pain) Toda (Pricking Pain)

\begin{tabular}{|l|l|c|}
\hline Absent & Noda (Pricking Pain) & Score \\
\hline Mild & Occasionally present Pricking Pain & 0 \\
\hline Moderate & $\begin{array}{l}\text { Frequently present Pricking Pain, } \\
\text { disturbing daily routine }\end{array}$ & 2 \\
\hline Severe & $\begin{array}{l}\text { Present throughout the day Pricking } \\
\text { Pain, disturbing daily routine }\end{array}$ & 3 \\
\hline
\end{tabular}

Table 6: Grading of Kandu (Itching)

\begin{tabular}{l|l|c|}
\hline Absent & $\begin{array}{l}\text { No Itching } \\
\text { Occasionally present Itching, not } \\
\text { disturbing daily routine }\end{array}$ & Score \\
\hline Moderate & $\begin{array}{l}\text { Frequently present Itching disturbing } \\
\text { daily routine }\end{array}$ & 2 \\
\hline Severe & $\begin{array}{l}\text { Present throughout the day Itching, } \\
\text { disturbing daily routine }\end{array}$ & 3 \\
\hline
\end{tabular}

Table 7: Grading of Swelling Swelling

\begin{tabular}{|c|c|c|}
\hline \multicolumn{2}{|r|}{$\mathrm{C}=11$} & \\
\hline Absent & No Swelling & 0 \\
\hline Mild & $\begin{array}{l}\text { Swelling present not disturbing daily } \\
\text { routine }\end{array}$ & 1 \\
\hline Moderate & $\begin{array}{l}\text { Swelling with minute opening present } \\
\text { not disturbing vision }\end{array}$ & 2 \\
\hline Severe & $\begin{array}{l}\text { Swelling with minute opening present } \\
\text { disturbing the vision }\end{array}$ & 3 \\
\hline
\end{tabular}


Table 8: Grading of Tenderness

\begin{tabular}{|l|c|c|}
\hline \multicolumn{1}{|c|}{ Tenderness } & Score \\
\hline Absent & No Tenderness & 0 \\
\hline Mild & Mild Tenderness & 1 \\
\hline Moderate & Moderate Tenderness & 2 \\
\hline Severe & Severe Tenderness & 3 \\
\hline
\end{tabular}

Table 9: Grading of Congestion

$$
\text { Congestion }
$$

\begin{tabular}{|l|l|l|}
\hline Absent & No Congestion & 0 \\
\hline Mild & Congestion over the swelling & 1 \\
\hline Moderate & Congestion over and nearby swelling & 2 \\
\hline Severe & $\begin{array}{l}\text { Congestion involves whole palpebral } \\
\text { conjunctiva }\end{array}$ & 3 \\
\hline
\end{tabular}

\section{Therapeutic intervention}

Treatments given to the patient have been enlisted in Table 10. Patient was advised to avoid direct sunlight, UV light and wind. Also, patient was advised to take proper sleep, avoid work near fire, dust and smoke.

\section{Follow up}

After completion of treatment, the patient was followed up for 7days. Patient was completely free from the previous signs and symptoms and no any new complaints were found during the $7^{\text {th }}$ day of follow up.

\section{Results}

After $5^{\text {th }}$ day of assessments, variations in results were found on each symptom associated with Anjananamika. Results of the treatment were tabulated and analyzed. Patient got relief in signs and symptoms with gradual improvement. Effects of the treatment on the patient are presented in Figure 1,2 and 3 . Assessment on each considering symptom of Anjananamika has been presented in Table 11 .

\section{Outcome}

It was observed that after 5 days of treatment, all the signs and symptoms were relieved completely.

Table 10: Posology of treatment protocol

\begin{tabular}{|l|l|l|l|l|}
\hline $\begin{array}{l}\text { Sr. } \\
\text { No }\end{array}$ & Drug & Dose & $\begin{array}{l}\text { Mode of } \\
\text { Administration }\end{array}$ & Duration \\
\hline 1 & $\begin{array}{l}\text { Patoladi } \\
\text { Kashaya }\end{array}$ & $\begin{array}{l}500 \mathrm{ml} \text { for } \\
10\end{array}$ & $\begin{array}{l}\text { Parisheka } \\
\text { minutes / } \\
\text { twice daily. }\end{array}$ & 5 Days \\
\hline 2 & $\begin{array}{l}\text { Quantity } \\
\text { sufficient } \\
\text { for } \\
\text { Bidalaka } \\
\text { for 10 } \\
\text { minutes } / \\
\text { twice daily. }\end{array}$ & $\begin{array}{l}\text { Midalaka } \\
\text { (Ocular } \\
\text { anointment) }\end{array}$ & 5 Days \\
\hline & & & \\
\hline
\end{tabular}

Table 11: Assessment on considering symptoms of Anjananamika.

\begin{tabular}{|r|l|c|c|}
$\begin{array}{r}\text { Sr. } \\
\text { No }\end{array}$ & Signs and Symptoms & $\begin{array}{c}\text { 1st Day } \\
\text { (Before } \\
\text { Treatment) }\end{array}$ & $\begin{array}{c}\mathbf{7}^{\text {th }} \\
\text { day } \\
\text { After } \\
\text { treatment }\end{array}$ \\
\hline 1 & $\begin{array}{l}\text { Daha (Burning } \\
\text { Sensation) }\end{array}$ & 0 \\
\hline 2 & Toda (Pricking Pain) & 3 & 0 \\
\hline 3 & Kandu (Itching) & 1 & 0 \\
\hline 4 & Swelling & 3 & 0 \\
\hline 5 & Tenderness & 2 & 0 \\
\hline 6 & Congestion & 3 & 0 \\
\hline
\end{tabular}

Figure 1 Before Treatment

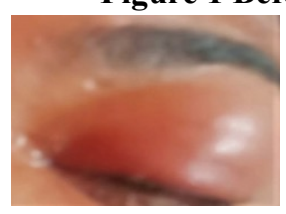

Figure 2 During Treatment (3rd day)

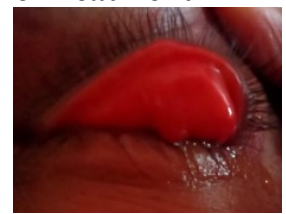

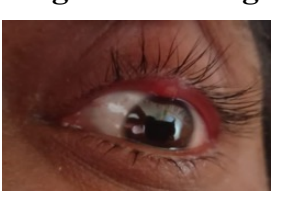

Figure 3 After Treatment (5 ${ }^{\text {th }}$ day)

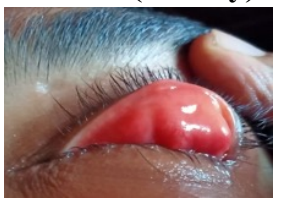

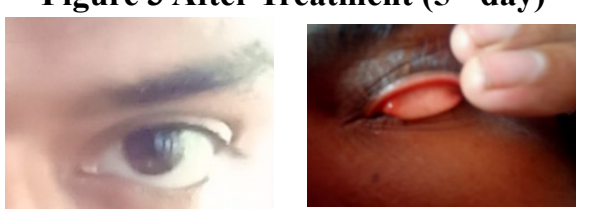

Table 12: Rasa Panchaka of Mukkadi Yoga(6)

\begin{tabular}{|c|c|c|c|c|c|c|c|}
\hline No & Drug & Botanical names & Rasa & Guna & Virya & Vipaka & Karma \\
\hline 1 & Hareetaki & $\begin{array}{l}\text { Terminalia chebula } \\
\text { Retz. }\end{array}$ & $\begin{array}{l}\text { Pancha rasa } \\
\text { (Kashaya pradhana } \\
\text { and Lavana varjita) }\end{array}$ & Laghu, Ruksha & Ushna & Madhura & $\begin{array}{l}\text { Tridoshaghna } \\
\text { Chakshushya } \\
\text { Rasayana } \\
\text { Lekhana }\end{array}$ \\
\hline 2 & Amalaki & $\begin{array}{l}\text { Embilica officinalis } \\
\text { Gaertn. }\end{array}$ & $\begin{array}{l}\text { Pancha rasa (Amla } \\
\text { pradhana and } \\
\text { Lavana varjita) }\end{array}$ & Laghu, Ruksha & Sheeta & Madhura & $\begin{array}{l}\text { Kapha } \\
\text { Pittahara } \\
\text { Chakshushya } \\
\text { Rasayana } \\
\text { Bhedana }\end{array}$ \\
\hline 3 & Bibhitaka & $\begin{array}{l}\text { Terminalia bellerica } \\
\text { Roxb. }\end{array}$ & Kashaya & Laghu, Ruksha & Ushna & Madhura & $\begin{array}{l}\text { Kapha } \\
\text { Pittahara } \\
\text { Chakshushya } \\
\text { Rasayana } \\
\text { Bhedana }\end{array}$ \\
\hline 4 & Gairika & Red ochre feo. & $\begin{array}{l}\text { Kashaya } \\
\text { Madhura }\end{array}$ & $\begin{array}{l}\text { Snigdha } \\
\text { Vishada }\end{array}$ & Sheeta & Madhura & $\begin{array}{l}\text { Pitta nasaka } \\
\text { Vrnaropaka } \\
\text { Kaphahara } \\
\text { Netrya }\end{array}$ \\
\hline
\end{tabular}


Vidya N V et.al., Efficacy of Mukkadi Bidalaka and Patoladi Kashaya Parisheka in the management of Anjananamika

\begin{tabular}{|c|c|c|c|c|c|c|c|}
\hline 5 & Chandana & $\begin{array}{l}\text { Santalum album } \\
\text { Linn. }\end{array}$ & $\begin{array}{l}\text { Tikta } \\
\text { Madhura }\end{array}$ & Laghu, Ruksha & Sheeta & Katu & $\begin{array}{l}\text { Kapha } \\
\text { Pittahara } \\
\text { Daha } \\
\text { prasamana } \\
\text { Kandughna }\end{array}$ \\
\hline 6 & $\begin{array}{l}\text { Raktha } \\
\text { Chandana }\end{array}$ & $\begin{array}{l}\text { Pterocarpus } \\
\text { santalinus L.f }\end{array}$ & $\begin{array}{l}\text { Tikta } \\
\text { Madhura }\end{array}$ & Guru & Sheeta & Katu & $\begin{array}{l}\text { Kapha } \\
\text { Pittahara } \\
\text { Chakshushya }\end{array}$ \\
\hline 7 & Haridra & Curcuma longa Linn. & $\begin{array}{l}\text { Tikta } \\
\text { Katu }\end{array}$ & Laghu, Ruksha & Ushna & Katu & $\begin{array}{l}\text { Rakta Vikara } \\
\text { Shodha }\end{array}$ \\
\hline 8 & Daruharidra & Berberis aristata DC. & $\begin{array}{l}\text { Fruit-Madhura } \\
\text { Amla, Kashaya, } \\
\text { Bark-Tikta, Kashaya }\end{array}$ & Laghu, Ruksha & Ushna & Katu & $\begin{array}{l}\text { Netra Rogahara } \\
\text { Deepana } \\
\text { Pachana }\end{array}$ \\
\hline 9 & Lodhra & $\begin{array}{l}\text { Symplococcus } \\
\text { racemosus Roxb. }\end{array}$ & Kashaya & Laghu, Ruksha & Sheeta & Katu & $\begin{array}{l}\text { Kapha } \\
\text { Pittahara } \\
\text { Chakshushya } \\
\text { Shodhahara }\end{array}$ \\
\hline 10 & Sariba & $\begin{array}{l}\text { Hemidesmus indicus } \\
\mathrm{R} \mathrm{Br}\end{array}$ & $\begin{array}{l}\text { Tikta } \\
\text { Madhura }\end{array}$ & $\begin{array}{l}\text { Guru } \\
\text { Snigdha }\end{array}$ & Sheeta & Madhura & $\begin{array}{l}\text { Vishanasana } \\
\text { Tridoshahara }\end{array}$ \\
\hline 11 & Vata & $\begin{array}{l}\text { Ficus bengalensis } \\
\text { Linn. }\end{array}$ & Kashaya & $\begin{array}{l}\text { Guru } \\
\text { Ruksha }\end{array}$ & Sheeta & Katu & $\begin{array}{l}\text { Vranahara } \\
\text { Dahaghna }\end{array}$ \\
\hline 12 & Durva & $\begin{array}{l}\text { Cynodon dactylon } \\
\text { Linn. }\end{array}$ & $\begin{array}{l}\text { Kashaya } \\
\text { Madhura }\end{array}$ & Laghu & Sheeta & Madhura & $\begin{array}{l}\text { Kapha } \\
\text { Pittahara } \\
\text { Dahagna } \\
\text { Raktapittahara }\end{array}$ \\
\hline 13 & Usheera & $\begin{array}{l}\text { Vetivera zizanoidis } \\
\text { Linn. }\end{array}$ & $\begin{array}{l}\text { Tikta } \\
\text { Madhura }\end{array}$ & Laghu, Ruksha & Sheeta & Katu & $\begin{array}{l}\text { Rakta } \\
\text { Vikarahara }\end{array}$ \\
\hline 14 & Nimba & $\begin{array}{l}\text { Azadirachta indica } \\
\text { Juss. }\end{array}$ & $\begin{array}{l}\text { Tikta, } \\
\text { Kashaya }\end{array}$ & Laghu, Ruksha & Ushna & Katu & $\begin{array}{l}\text { Tridosha } \\
\text { Shamaka }\end{array}$ \\
\hline
\end{tabular}

Table 12: Rasa Panchaka of Patoladi Kashaya (Anubhoota yoga)

\begin{tabular}{|c|c|c|c|c|c|c|c|}
\hline No & Drug & Botanical names & Rasa & Guna & Virya & Vipaka & Karma \\
\hline 1 & Patola & $\begin{array}{l}\text { Trichosanthes dioica } \\
\text { Roxb. }\end{array}$ & Tikta, katu & $\begin{array}{l}\text { Laghu, } \\
\text { ruksha }\end{array}$ & Ushna & Katu & Tridosha Shamaka \\
\hline 2 & Nimba & $\begin{array}{l}\text { Azadirachta indica } \\
\text { A.Juss. }\end{array}$ & $\begin{array}{l}\text { Tikta, } \\
\text { Kashaya }\end{array}$ & Laghu & Sheeta & Katu & $\begin{array}{l}\text { Vranahara, Dahahara, } \\
\text { Kandughna }\end{array}$ \\
\hline 3 & Jambu & $\begin{array}{l}\text { Syzigium cumini } \\
\text { Linn. }\end{array}$ & $\begin{array}{l}\text { Kashaya, } \\
\text { Madhura, Amla }\end{array}$ & $\begin{array}{l}\text { Laghu, } \\
\text { Ruksha }\end{array}$ & Sheeta & Katu & $\begin{array}{l}\text { Raktasrava Hara, } \\
\text { Vranaghna, Stambhaka }\end{array}$ \\
\hline 4 & Amra & $\begin{array}{l}\text { Mangifera indica } \\
\text { Linn. }\end{array}$ & Kashaya & $\begin{array}{l}\text { Laghu, } \\
\text { Ruksha }\end{array}$ & Sheeta & Katu & $\begin{array}{l}\text { Kaphapittashamaka, } \\
\text { Vranaghna }\end{array}$ \\
\hline 5 & Malati & $\begin{array}{l}\text { Aganosma } \\
\text { heynei(Spreng.) } \\
\text { ined. }\end{array}$ & Tikta, Kashaya & $\begin{array}{l}\text { Laghu, } \\
\text { Snigdha } \\
\text {, Mrudu }\end{array}$ & Ushna & Katu & $\begin{array}{l}\text { Tridosha Shamaka, Vranaropana, } \\
\text { Vranashodhana, Vedanasthapana }\end{array}$ \\
\hline
\end{tabular}

\section{Observations}

It was observed that the patient got complete relief from Anjananamika (Stye) in 5 days. He was asked to come for follow-up after 7 days, Patient was not on any medication at that time. There was no recurrence during the time of follow up.

\section{Discussion}

\section{Effect of treatment on Daha (Burning Sensation)}

The patient had complained of a frequent Burning sensation of both eyes, disturbing daily routine at first day of treatment, gradually it has been decreased to occasionally feeling of Burning sensation after 3 days and was completely cured after 5 days.

\section{Effect of treatment on Toda (Pricking Pain)}

The patient had complained of Pricking Pain throughout the day, disturbing daily routine at first day of treatment, gradually it has been decreased to occasionally feeling of Pricking Pain after 3 days and was completely cured after 5 days.

\section{Effect of treatment on Kandu (Itching)}

The patient had complained of Occasionally present Itching, not disturbing daily routine at first day of treatment, gradually it has been completely cured after 3 days.

\section{Effect of treatment on Swelling}

The patient had complained of Swelling with minute opening present disturbing the vision at first day of treatment, gradually it has been decreased to mild Swelling present not disturbing daily routine after 3 days and was completely cured after 5 days.

\section{Effect of treatment on Tenderness}

The patient had complained of Moderate Tenderness at first day of treatment, gradually it has been decreased to mild feeling of Tenderness 3 days and was completely cured after 5 days. 


\section{Effect of treatment on Congestion}

The patient had complained of Congestion involves whole palpebral conjunctiva at first day of treatment, gradually it has been decreased to mild Congestion over the swelling after 3 days and was completely cured after 5 days.

\section{Mode of action of Patoladi Kashaya}

If the symptoms are mild then Hot compression is enough to reduce the disease. If the symptoms are severe, incision and drainage is the only choice which is performed under local anaesthesia. (7) Ayurveda also advices to perform Bhedana Karma. Netra Seka with Patoladi Kashaya having Mrudu Swedana Tridosha Shamaka property may act as Dosha Vilayana which relieves the blockage of Meibomian glands. So, Patoladi Kashaya can perform Shamana and Shodana of Doshas.

Patola-has an excellent quality which purifies the Raktadhatu. It also possesses qualities like Sarvadoshaghna, Kandughna (which reduces itching), Krumighna (anti-microbial). It also supports the body's immune system and also good for eyes. (8)

Nimba- The chemical constituent Nimbidin present in this drug is having anti-inflammatory action and many extracts are having anti-microbial property. (9)

Jambu- Dihydromyrecitin present in this drug is having anti-biotic, anti-inflammatory as well as anti-pyretic property. (10)

Amra- Good for eyes, having anti-bacterial property, enhances immune power. (11)

Malati- Leaf juice of Malati is having antibiotic effect. (12)

\section{Probable mode of Action}

Instillation of medicated solution in to the partially opened eye, continuously for a stipulated time period. It is indicated in the acute phase of inflammation whereas in the corneal and conjunctival epithelia permeability is high, hence the absorption is more. Disposal and tissue contact time is more in Parisheka than in Aschyotana. Absorption of drug through conjunctival epithelia reduces the sign and symptoms of Anjananamika (Stye).

\section{Mode of action of Mukkadi Yoga}

In Bidalaka topical application of drugs in the form of paste over the skin of lids are indicated in acute inflammatory conditions of the lids. Mukkadi Yoga is one such formulation explained in Sahasrayogam, a very popular medical text in Malayalam language. Mukkadi Yoga is a Bidalaka Yoga told in Urdwanga Roga Chikitsa under the Vartmarogachikitsa Prakarana of Sahasrayogam text which is said to be useful in inflammatory signs and symptoms of eye i.e. Sopha, Ruja, Daha, Raga etc.(13) The drug is absorbed through the skin acts locally, as well as by the vasodilation and drainage of toxins from the site of application. The contents are predominantly cooling, works on vitiated Pitta and Rakta and majority have haemostatic activity. Hence it has been selected for trans-dermal absorption as a Pittashamaka action. Slight acidic nature of Mukkadi Yoga which may help in augmenting the function of Brajaka Pitta ultimately work as a transdermal action.

\section{Conclusion}

Mukkadi Bidalaka and Patoladi Kashaya Parisheka in Anjananamika found to be effective in reducing signs and symptoms of Anjananamika and significant results were seen. No adverse and toxic effects were observed during and after the completion of treatment. Modern ophthalmologists suggest Systemic anti-inflammatory and analgesics relieve pain and reduce edema, and eye ointment at bed time, which may have many side effects. These may cause temporary stinging, swelling, burning sensation and irritation to the eyes. But in Ayurveda, Anjananamika (Stye) can be treated with Netra Kriyakalpa like Parisheka and Bidalaka to prevent the recurrence of the disease. Therefore, Mukkadi Bidalaka and Patoladi Kashaya Parisheka can be used safely and effectively in the treatment of Anjananamika (Stye). The recovery in the present case was promising and worth documenting. Further, more trials with these medicines for a large number of patients can be done since enough studies have not carried out with this combination of the drugs.

\section{References}

1. Sushrut Samhita, Uttar Tantra, Trutiykhanda, Trividha vartmaroga vijnyan, Acharya Priyavat Sharma, Chaukhamba Surbharati Prakashan, Varanasi, 2012, Page.No.24.

2. Ashtangahrudayam Utharasthanam,Commentary by Cheppatt Achyutha Variyar,13 th Reprint July 2009,Devi book stall Kodungallor,Page.No.122.

3. Comprehensive Opthalmology, A.K.Khurana, Disease of eyelids, Jypee brothers medical publishers, Seventh Edition 2019, Page No.383.

4. Srikanta Murthy KR. Bhedhyarogapratishedha. Sushruta Samhita. Anjananamika: Chikitsa. Chaukhambha Orientalia, Varanasi. Reprint. Uttara sthana 14th chapter; 2012. Page No.621.

5. Srikanta Murthy K R. Vartmarogapratishedha. Ashtanga Hridaya. Anjananamika: chikitsa. Chaukhambha Krishnadas Academy, Varanasi. 6 $6^{\text {thed. }}$ Reprint. Uttara sthana $8^{\text {th }}$ chapter; 2012. Page No.76.

6. Krishnan Vaidyan K.V. \& S. Gopala Pillai, Sahasrayogam, 33 ${ }^{\text {rd }}$ edition, Vidyarambham Publishers, Mullakkal, Alappuzha; Feb 2015, page no. 381

7. Pratibha Upadhyay, Shamsa Fiaz, Role of Triphaladi Parisheka in Lid concretion; A Case Study, Global Journal of Medical Research (F ), Vol 17 Issue1 Version 1. 0 Year 2017. Publisher: Global Journals Inc. (USA). 
8. Shastry J L N, Illustrated Dravyaguna Vijnana vol-2, 2005 edition, chaukhamba Orientalia, 250.

9. Shastry J L N, Illustrated Dravyaguna Vijnana vol-2, 2005 edition, chaukhamba Orientalia, 123.

10. Shastry J L N, Illustrated Dravyaguna Vijnana vol-2, 2005 edition, chaukhamba Orientalia, pg-228.

11. Shastry J L N, Illustrated Dravyaguna Vijnana vol-2, 2005 edition, chaukhamba Orientalia, 681.
12. Shastry J L N, Illustrated Dravyaguna Vijnana vol-2, 2005 edition, chaukhamba Orientalia, pg-681.

13. Krishnan Vaidyan K.V. \& S. Gopala Pillai, Sahasrayogam, 33rd edition, Vidyarambham Publishers, Mullakkal, Alappuzha; Feb 2015, page no. 381 . 